\title{
Contractual and Consensual Profiles for an Interorganizational Governance of Information Technology
}

\author{
Anne-Marie Croteau ${ }^{1}$, François Bergeron ${ }^{2} \&$ Jason Dubsky $^{1}$ \\ ${ }^{1}$ John Molson School of Business, Concordia University, Canada \\ ${ }^{2}$ Ecole des sciences de l'administration, TELUQ, Canada \\ Correspondence: François Bergeron, Ecole des sciences de l'administration (ESA), TELUQ, 455 du Parvis, \\ Québec, Québec, G1K 9H6, Canada. Tel: 1-418-657-2747. E-mail: francois.bergeron@teluq.ca
}

\author{
Received: September 17, 2012 Accepted: October 11, $2012 \quad$ Online Published: August 20, 2013 \\ doi:10.5539/ibr.v6n9p30 URL: http://dx.doi.org/10.5539/ibr.v6n9p30
}

\begin{abstract}
Two profiles of interorganizational governance of IT were obtained from interviews conducted with leaders involved in setting the governance mechanism needed to support successful IT collaboration with their business partners. Three attributes, based on literature from network governance streams, were used to uncover those profiles. They are the IT governance structure, the processes put in place to make decisions, and the roles of participants involved in setting the interorganizational governance mechanisms. Observed profiles share a continuum where the Contractual profile is at one end, and the Consensual profile is at the other end. Some performance variations among the two profiles exist, yet both profiles contribute to successful interorganizational relationships. These profiles were uncovered from seven case studies conducted in Canadian organizations. Through fifteen interviews with senior interorganizational IT governance committee members and IT executives, the critical IT governance mechanisms they employed were identified. Two cases are reported in this article, each one illustrating respectively the Contractual and the Consensual profiles.
\end{abstract}

Keywords: governance, interorganizational, profiles, contractual, consensual, information technology

\section{Introduction}

This article focuses on the elaboration of potential profiles of governance mechanisms that are put in place to contribute to the success of interorganizational governance of information technology (IT). Three attributes, based on the network governance literature, were used to define the potential profiles: the IT governance structure, the process of decision making and the role of participants involved in the interorganizational governance of IT. This study follows previous calls for further research on interorganizational governance of IT made by Croteau and Bergeron (2009) and Croteau and Dubsky (2011), who indicated that there is a need to better understand this particular type of IT governance.

IT governance is a prime concern for both businesses and academics (Brown \& Grant, 2005; Weill \& Ross, 2004; Sambamurthy \& Zmud, 1999). Even with all of today's latest advances in research, development and implementation of IT capabilities, organizations continue to struggle to attain alignment between IT activities and business objectives in order to achieve value with their IT investments, modeling their processes for specific business needs and customized IT solutions. Although, it was found that organizations that reach a certain level of alignment between their business and IT domains managed to put in place a broad set of IT governance practices (De Haes \& Van Grembergen, 2009).

Businesses strive to couple their operational and IT processes in order to cut costs and increase efficiency. Furthermore, interorganizational exchanges continue to increase in frequency and value. While these exchanges evolve and mature, with this evolution comes opportunism, a negative yet inevitable consequence of interorganizational exchange (Goo, Kishore, \& Rao, 2009). Firms in today's volatile market strive to increase the value of their IT investments; in doing so, the current trends, and even the next generation of strategies, have come to emphasize collaborative partnerships in the form of interorganizational relationships. The combination of firms' capabilities allow these firms to more easily control and adapt to market forces and uncertainties (Brown \& Grant, 2005; Chi \& Holsapple, 2005). These partnerships induced an added role for IT, which is a cooperation enabler between businesses (Hong, 2002). In fact, IT is now seen as the primary enabler of new business activities between 
firms; e-business has become the dominant paradigm in a progressively electronic economy (Patrakosol \& Olson, 2007). A firm can only create so much competitive advantage on its own. A group of firms working together, however, can make all the difference (Hong, 2002).

The various mechanisms of interorganizational governance of IT that are put in place by organizations when exchanging with their business partners are studied here, bringing into consideration concepts from both fields of interorganizational relationship and IT governance. This research provides some answers to the following research question: Do mechanisms of interorganizational governance of IT exist? If they do, could profiles of such mechanisms be identified?

\section{Background}

In order to better answer our research question, some key concepts are reviewed in this section. We first address the notion of IT governance and its mechanism as defined within an organization. Given the interorganizational aspect of governance that we want to address, we then look at what is known regarding interorganizational relationships and their forms of governance. Having covered those key concepts, we can then describe the key attributes of mechanisms of interorganizational governance of IT. We conclude this section by identifying the main characteristics of successful interorganizational relationships.

\subsection{IT Governance}

Business executives have come to the conclusion that they cannot conduct day-to-day activities, including production, marketing, or research, without relying heavily on IT and IT decisions; therefore delegating and/or ignoring these decisions puts organisations at risk and calls for another mechanism of decision-making regarding IT, that is called IT governance (Peterson, 2004). IT governance should increase value, manage risk, maintain accountability and measure programs and activities (Brown \& Grant, 2005; Van Grembergen, De Haes, \& Guldentops, 2004). As indicated by Weill (2004), "governance is about systematically determining who makes each type of decision (a decision right), who has input to a decision (an input right) and how these people (or groups) are held accountable for their role. Good IT governance draws on corporate governance principles to manage and use IT to achieve corporate performance goals" (p. 3). While structural, process, and relational capabilities are an integral part of effective IT governance (Peterson, 2004), IT governance specifies the decision rights and accountability framework to encourage desirable behavior in the use of IT (Weill \& Ross, 2004).

\subsection{IT Governance Mechanisms}

IT governance mechanisms research deals with the decision-making structures adopted by IT organizations (Zmud, Boynton, \& Jacobs, 1986; Brown \& Magill, 1994). Previous research has attempted to categorize IT governance mechanisms. Early research found four archetypes called centralized, decentralized, federal, and hybrid (Brown, 1997; Brown \& Magill 1994). More recently, six archetypes were identified by Weill and Ross (2004) and were labeled based on whom was serving on the committees, providing input and making decisions about five main IT governance domains: business monarchy, IT monarchy, federal, feudal, IT duopoly and anarchy. Taking a different approach, Xue, Liang and Boulton (2008) uncovered seven archetypes: top management monarchy, top management-IT duopoly, IT monarchy, administration monarchy, administration-IT duopoly, professional monarchy, and professional-IT duopoly. Such archetypes were revealed through four attributes, IT investment level, external influence, organizational centralization, and IT function power.

All these mechanisms lie on a common decision-making continuum ranging from centralized to decentralized. Centralized governance forms place the decision-making authority into the hands of a small group of individuals within the firm, usually within the upper echelons of management and/or executives. Decentralized governance forms, on the other hand, relegate the decision-making authority to the business units, allowing each operator to create its own set of regulations and generate policy thusly (Brown, 1997; Kayworth \& Sambamurthy, 2000). It was observed by Brown and Grant (2005) that centralizing IT governance provided more control and opportunity while decentralizing IT governance provided more flexibility and responsiveness. Centralized IT governance places the burden of decision-making at the center of the IS function in the organization: the CIO, IS executives and management. It contributes to operational efficiencies because of the economies of scale (Hvalshagen, 2004). A central IT governance mechanism is best suited for firms that take a corporate approach in better integrating diversified yet related strategies (Brown \& Magill, 1994). More centralized governance mechanisms like business and IT monarchies of Weill and Ross (2004) are more appropriate for organizations that aim at greater profitability and that put the necessary efforts on better organisational integration and choosing the right competencies.

Conversely, decentralized IT governance spreads the decision-making authority to the various business units and their management; decentralization often helps business unit managers to have a better understanding of the 
contribution of IT activities to their operations (Hvalshagen, 2004; Brown, 1997; Sambamurthy \& Zmud, 1999). The overall effect is a redistribution of accountability; centralized forms allow for greater control while decentralized forms offer greater flexibility. Organizations that strategically emphasize business unit innovation through a limited number of processes are better served by decentralized IT governance mechanisms like the feudal one (Weill \& Ross, 2004) While centralized and decentralized mechanisms have their pros and cons, neither one can claim optimality even if they share the same continuum (Kayworth \& Sambamurthy, 2000).

\subsection{Interorganizational Relationships}

The formation of an interorganizational relationship is itself a strategic decision (Heide, 1994). There are two fundamental stances or views when it comes to interaction with other firms: competition and collaboration (Huxham \& Vangen, 1996). While competition and competitive advantage are a given in modern markets, cooperation is an attitude that requires appropriate strategy in order to guarantee success.

Firms create interorganizational relationships with other firms in order to achieve goals that each firm would not easily be able to attain when acting alone (Lee \& Lim, 2005). External pressures, including environmental and technological standards, as well as internal firm pressures, are moving firms to seek cooperation in areas previously unsearched (Ring \& Van de Ven, 1992). As such, interorganizational relationships allow firms to combine resources and share knowledge, minimize risks, optimize asset use, increase competitive or market power, maximize their ability to offer attractive products and services, increase efficiency, to reduce costs, increase flexibility, collective lobbying and neutralizing or blocking competitors, increase sales volume, accelerate technology development, open market access, or capitalize on opportunities for organizational learning (Doz \& Hamel, 1998; Barringer \& Harrison, 2000; Hamel, 1991; Koh \& Venkatraman, 1991; Powell, 1990; Ritter, 1999). Advantages exist, though often they are not visible and/or definable at the beginning of the relationship (Lowndes \& Skelcher, 1998).

However, the decision to undertake these relationships is often based on multiple factors or contingencies; firms will often weigh the pros and cons of each relationship, and each firm will have its own ultimate deciding factors that lead it to initiate the relationship (Oliver, 1990; Lee, Miranda, \& Kim, 2004; Goo et al., 2009). Firms tend to progress cautiously into relationships, sending signals as they progress, and define their evolution in stages, as step-by-step progress with the evaluation of potential partners and initial negotiations, and preliminary adaptation efforts (Larson, 1992; Dwyer, Schurr, \& Oh, 1987).

Barringer and Harrison (2000) summarize that the theories of interorganizational relationships fall within a gamut between economic rationale and behavioural rationale. Transaction cost economics, resource dependency and strategic choice tend to fall under economic rationale; here, the fundamental decision element in transaction governance is "make or buy" (Lee, Miranda, \& Kim, 2004). Alternately, whereas stakeholder theory, learning theory and institutional theory are founded under behavioural rationale, the decision-making is not so clear cut, and falls under contingency theory. Each of these theories has several streams of research that provide a piece of the puzzle when it comes to deciphering the why's and how's of interorganizational relationships. Overall, however, most literature is organized around the simple advantages of interorganizational relationships and how those advantages outweigh the disadvantages.

These disadvantages have also been outlined by research. Aside from the fact that a large portion of interorganizational relationships fail, or at least fail at meeting the expectations of their participants, loss of proprietary information, management complexities, financial and organizational risks, risk becoming dependent on a partner, partial loss of decision autonomy, culture clash, loss of organizational flexibility and antitrust implications are all potential worries that need to be accounted for and carefully weighed at the inception and development of any interorganizational relationship, a difficult task to manage (Barringer \& Harrison, 2000). Furthermore, relationship maintenance requires careful planning of future contingencies and changing factors (Barney \& Ouchi, 1986; Macaulay, 1963), as well as mechanisms that adapt to the changes in the relationship itself (Wachter \& Williamson, 1978), and maintaining an interorganizational relationship requires heavy commitment from all involved (Lee \& Lim, 2005). Furthermore, the formalization of commitments, in the form of contractual obligations - such as service level agreements - can cause opportunism, an "ugly" side effect of mutual dependence (Goo et al., 2009).

\subsection{Forms of Governance Relationships}

One of the latest trends in the modern economy is the vertical disintegration of corporations. The creation of a governance framework that allows for adequate control and flexibility when dealing with this disintegration is necessary. Based on Williamson (1975), Powell (1990) describes three forms of relationship governance: market, hierarchy and network. Markets and hierarchies exist as endpoints on a linear scale: market governance seeks to 
enable transaction-specific straightforward business exchanges, while hierarchy governance is best suited for those uncertain repeating relationships with non-standard requirements. However, Powell argues that this paradigm exists to create indebtedness between parties. The need for relationships definitions whereby the partners act reciprocally and in an accommodating way is left untouched in this scale. This, along with economic incentives and strategic rewards as precedent (Larson, 1992), has led to new forms of network governance (Gereffi, Humphrey, \& Sturgeon, 2005).

Jones, Hesterly, and Borgatti (1997) describe a network as the involvement of "select, persistent, and structured $\mathrm{set}[\mathrm{s}]$ of autonomous firms (as well as non-profit agencies) engaged in creating products or services based on implicit and open-ended contracts to adapt to environmental contingencies and to coordinate and safeguard exchanges" (p. 914). Podolny and Page (1998) define networks as "as any collection of actors (N $\geq 2$ ) that pursue repeated, enduring exchange relations with any one another and, at the same time, lack a legitimate organizational authority to arbitrate and resolve disputes that may arise during the exchange" (p. 59). Networks lack the bureaucratic structures often present in other formal governance paradigms (Jones et al., 1997).

The common link between these definitions is twofold: the repeated business exchanges as well as the informality of the relationship. Network forms are more social than markets or hierarchies; while not guided by formal rules, regulations or bodies, networks rely on the participants' mutual interests and respect, and are exemplified by reciprocal patterns of communication and exchange. Furthermore, social controls, including trust, mutual dependence and reputation, are inherent in the genesis of a socially-based relationship (Powell, 1990; Goo et al., 2009).

\subsection{Attributes of Mechanisms of Interorganizational Governance of IT}

The main contribution of this research is to mix the concepts of IT governance, interorganizational relationships and network governance into a new hybrid research avenue. Research in the field of IT governance is extensive, as is research in the field of interorganizational relationships; however, not much has been done in the area of interorganizational governance of IT.

This study ascertain how organizations govern their IT practices and create IT policies during business exchanges using the foundation of constructs in Powell's network governance framework (Powell, 1990). Although IT governance has most of the time been applied from an internal perspective (Sambamurthy \& Zmud, 1999), there is a need to study its interorganizational aspect. Therefore, interorganizational governance of IT is defined as "the authority and accountability frameworks put in place to encourage the efficient and effective use of IT when sustaining electronic exchanges among business partners" (Croteau \& Bergeron, 2009, p. 3).

In order to maintain a level or manageability to the data, three attributes are used to define the profiles of interorganizational governance of IT. They are the structure of the governance mechanisms, the types of participants implied in the interorganizational relationships, and the processes they follow to exercise their control. Such attributes were initially proposed by Winkler (2006) as attributes of interorganizational governance and were found to be pertinent attributes for conducting research on interorganizational governance of IT (Croteau \& Bergeron, 2009; Croteau \& Dubsky, 2011).

Structure refers to the way through which tasks are distributed within an organization and the channels of connections among various organizational positions (Kumar \& Van Dissel, 1996). In other words, structure determines the locus of authority for each position within an organization and hence is critical in the configuration of the organizational resources (Hall \& Saias, 1980). When applied to interorganizational governance mechanisms, structure shapes and influences the agendas between organizations by determining who has the power to act, and what resources between business partners are exploited (Winkler, 2006; Huxham \& Vangen, 2000). Therefore, the structureconstruct corresponds to the ways in which interorganizational decisional work is divided among the partnering organizations by assigning specific roles to these organizations and the ways in which coordination is achieved among these roles (Kumar \& van Dissel, 1996).

During interorganizational governance mechanisms, the collaborative participants are defined by individuals involved in the governance of IT on either side of the relationship(s), but also by people - executives, managers and other leaders - who have a stake in the success of the business relationship, both directly and indirectly (Huxham \& Vangen, 2000). While there exist several combinatorial participant forms, including boards, steering committees and groups, a line is drawn that separates policy-makers from other participants. Participants are classified as belonging to one of two categories: those with executive participation and those without, as these categorical restrictions parallel the leadership roles suggested by Huxham and Vangen (2000). By assessing the participant construct, this research aims at identifying who makes decisions when it comes to IT governance from an interorganizational perspective, who is involved in the inception, creation and/or implementation of IT 
governance structure during the creation of a new relationship, the processes followed to make decision, and at what level of their respective organization participants are.

Processes refer to "the interunit or interfirm activities that accompany exchange within the framework of the governance structure" (Zaheer \& Venkatraman, 1995, p.375). These processes allow partnership members to communicate efficiently and effectively, providing appropriate resources given the structure. Processes affect participants' behaviour and therefore can be a turning point that will enhance or not the performance of organizations that are part of the network; after all, poorly designed processes can be counterproductive (Meyer, 2004). If participants invest adequately into proper decision-making processes, and not just in structures, IT value is more likely to be increased (Weill \& Ross, 2005). Processes put in place in this context are defined as the formal and informal control tools by which the communication among business partners takes place to make decisions about common projects. These formal and informal instruments of control are often influenced by standards set about by the firm, industry or market. Standards related to SOX (Sarbanes-Oxley or Sarbox), COBIT (Control Objectives for Information and related Technology) or ITIL (IT Infrastructure Library) can be defined as agreed-upon specifications for a way of communicating or performing actions related to IT. The present research will attempt to identify whether a firm is using formal or informal processes and if they are standardized or not in their interorganizational dealings.

\subsection{Success of Interorganizational Relationships}

Oliver (1990) identifies six critical contingencies for the success of relationships: necessity, asymmetry, reciprocity, efficiency, stability and legitimacy. These can be paralleled with Lu, Huang and Heng's (2006) characteristics of interorganizational systems versus simple information systems: cooperation, standards, third party involvement, synchronicity, the need for relationships, and openness. Competitive necessity determines the need for relationships, and contributes to successful IOS planning and implementation (Lin, 2006). Asymmetry often requires the involvement of a third party to arbitrate, as smaller organizations seek to partner with larger companies to take advantage of financial resources (Slowinski, Seelig, \& Hull, 1996). Reciprocity begets cooperation, allowing all participants a web of resources between units, and thus each unit in the exchange is dependant to a certain degree on each of the other members; removing a unit will affect each other unit to varying degrees (Kumar \& van Dissel, 1996).

Furthermore, the development of reciprocal relationships enables long-term collaborative development (Lowndes \& Skelcher, 1998). Efficiency simply requires synchronicity; attempting to improve the use of all participants' resources requires coordination, and a lack of synchronicity simply implies a certain level of waste (Oliver, 1990). Standards are derived and adopted in order to satisfy a maximum of complexity (Gereffi et al., 2005) in the processes, satisfying a requirement of stability by attempting to minimize error (Chi \& Holsapple, 2005). Finally, relationships cannot be legitimate without a certain level of openness. For our research, interorganizational relationships were considered successful when all parties could say that they have reached their goals, in a satisfying mode.

\section{Methodology}

Grounded in the configurational theory, this research aims at validating if mechanisms of interorganizational governance of IT exist, and if possible to classify them in profiles. Therefore, a subjective approach to the validation of such mechanisms seems to be the best fit for this research (Lee, 1989). Case-based research is seen as one of the leading approaches to academic research in IT. Case studies allow for current-day data to be proliferated into academic research. Furthermore, the case-study approach allows for a flexible and dynamic form of data collection, paralleling the dynamic nature of the data itself. Lastly, case analysis allows for researchers to spawn new ideas and generate interest and questions in the research stream that were unforeseen or unknown during the research genesis (Dubé \& Paré, 2003).

The following steps were undertaken when designing this research in order to create a robust exploratory case-based investigation, as per recommendations provided by Dubé \& Paré (2003): a) Clear, concise and precisely defined research questions were devised from the literature in order identify profiles of interorganizational governance of IT; b) A pilot research investigation was devised and undertaken in order to reveal potential inadequacies in the identification of potential attributes; c) A multiple-case research design was effected in order to provide robust positivist data to uncover possible profiles; and d) All data collection processes were elucidated in order to provide transparency.

Thirty-two organizations were canvassed for interviews with IT managers and/or executives that might be able to provide data in order to build case studies. Of these organizations, 15 interviews were conducted across 11 
organizations over a period of 6 months, sporadically given participant availabilities, in order to maximize the number of case studies and thus the rigour of this research.

Qualitative data was gathered by interviewing managers and executives from participating organizations. There were no limits placed regarding the size or market of the organization; the only requirement was that IT played a role in their day-to-day operations. Participation in the study was voluntary. Interviewees were required to: a) Be knowledgeable about the concepts of IT governance; b) Be involved with the IT governance of their organizations, c) Be involved in interorganizational dealings, and d) Be involved in the decision-making process of each of the above.

A minimum of one hour was required by the researcher for each interview, though the interview may have lasted longer depending on the nature of the conversation and the participant's available time. Participants were also informed that a second interview could be requested if clarification was required. A questionnaire was provided to each of the willing participants ahead of time via email and participants were informed that questions would be of this nature during the interview, though not necessarily following the specific questions outlined. It was deemed by the researcher that given the informal nature of the interview as well as the variability of participants' knowledge and experience, following a strict questionnaire script would limit the effectiveness of the interview. Face-to-face interviews were requested by the researcher and, failing this because of logistical or scheduling barriers, phone interviews were requested as a second option.

\section{Uncovering Mechanisms of Interorganizational Governance of IT}

This research aimed at answering if mechanisms of interorganizational governance of IT exist; and if they, what profiles of such mechanisms could be defined. This section reports the emergent key categories of the attributes of interorganizational governance of IT. The attributes of structure, process and participants were categorized based on the observations obtained during the interview. A summary of the results is reported in Table 1. Names of the participants and the organizations have been withheld to ensure privacy and anonymity. Therefore each organization has been nicknamed according to its operations and market.

Table 1. Case studies results

\begin{tabular}{|c|c|c|c|c|c|}
\hline & Structure & Process & Participants & & \\
\hline Centralized & $\mathrm{a}, \mathbf{F}, \mathrm{g}$ & & & & \\
\hline Networked & $\mathrm{b}, \mathbf{C}, \mathrm{d}$ & & & & Legend \\
\hline Value-chain & $\mathrm{e}$ & & & $\mathrm{a}$ & Outsourced bank IT \\
\hline Inward & & $\mathrm{e}, \mathbf{F}$ & & $\mathrm{b}$ & Coop bank venture \\
\hline Outward & & $\mathrm{b}, \mathbf{C}, \mathrm{d}$ & & $\mathbf{C}$ & Railway \\
\hline In/Outward & & a & & d & Gaming \\
\hline Unilateral & & & $\mathrm{g}$ & e & Gaming research \\
\hline Bilateral & & & $\mathrm{d}, \mathrm{e}$ & $\mathbf{F}$ & Jetliner \\
\hline Committee & & & $\mathrm{a}, \mathrm{b}, \mathbf{C}, \mathbf{F}$ & $\mathrm{g}$ & University \\
\hline
\end{tabular}

Findings uncovered three emergent interorganizational IT governance structure categories: centralized form, networked form and value-chain form. These three categories demonstrate a relationship closeness that defines the structure of the inter-firm governance, with the centralized form representing a highly interdependent, highly strategic venture; a value-chain form representing a loosely connected, relatively simple trade partnership; and a networked form representing an interdependent, collaborative venture.

Both the centralized form and the network form were popular governance structures. Conversely, the value-chain form was not a particularly attractive governance structure category although it could be considered strategic depending upon the viewpoint the firms attribute to their relative power (Chou, Huang, \& Chen, 2012)

Three emergent interorganizational IT governance process were found: inward focus, representing a focus on interorganizational process formalization, outward focus, representing a focus on market process standardization, and a mix of both called in/outward focus. The process focus was evenly split between inward and outward focus. This suggests that organizations may put equal weight on both standardizing and formalizing governance 
processes. Furthermore, it may be that process focus may be situational; given the specific requirements of an interorganizational relationship, firms may choose to focus their interorganizational processes inwards and formalize, or they may choose to focus their interorganizational processes outwards and set/adopt standards. Only one organization had a mix of both focuses.

Three emergent interorganizational IT governance participant groupings were observed. The unilateral group is represented by one firm dominating participation and making unilateral decisions, often as per the recommendation of a single executive or CIO. The bilateral group is represented by the two participating firms in equal partnership, providing equal input, often at the level of paired executives being the ultimate decision-makers. Lastly, the committee group is represented by a multi-person collective, often with several representatives from multiple levels at both organizations, gathering in order to make decisions by committee.

Committee-based participant groupings were by far the most popular choice when it came to deciding where the responsibility and decision-making would lie. Committees infer both a generally decentralized approach to interorganizational governance as well as a shift away from dominance in partnerships - a level playing field between each organization. At the same time, only one relationship studied demonstrated properties of the unilateral participant grouping.

Many organizations chose to evaluate the success of the relationship subjectively by agglomerating affected factors such as increased efficiencies, value-adding aspects, increased competitiveness, product development ability, synergies and functional/operational requirements improvement. Therefore, it can be observed that the success of the relationship, while not strictly defined, can be derived by the operational goal of the relationship.

\section{Case studies}

While results indicated in Table 1 demonstrate that there is no distinctly dominant pattern or configuration of constructs, two main profiles can be derived: Contractual and Consensual. Contractual profiles refer to the fact that organizations are involved in a legal relationship with their outsourcers (Lacity, Khan, \& Willcocks, 2009) whereas the consensual profiles refer to a collaborative and cooperative approach (Zarvić, Stolze, Boehm, \& Thomas, 2012) to resolve issues they may have with their business partners.

The following two cases illustrate those two profiles. Jetliner (contractual profile) and Rail (consensual profile) were chosen among the seven interorganizational relationships and mechanisms of IT governance studied reported above. They were chosen because of their specific characteristics that make them distinct and a fair representation of each profile.

\subsection{Jetliner}

Jetliner is a major North American airline that outsourced its entire IT function in the mid 1990's to Sourcer. The organization subsequently back-sourced certain strategic portions ten years later, including business analysis and software development. It centralized its entire IT budget under the CIO in order to maintain a maximal level of control and ensure accountability at the highest level. Jetliner used several committees to generate all propositions and recommendations to the executive committee, including standards committees and architecture committees. All committees generated business cases and presented them for budgetary approval from the CIO. Steering committees provided all recommendations to the business.

Structure All of Jetliner relationships existed at the business level, and most of them were structured as sourcing relationships. As such, the business always spoke directly to the outsourcee. As Sourcer saw Jetliner as a project client, Sourcer's organizational structure was an outsourcer project model. Sourcer mimicked Jetliner IT structure. The executive relationship manager at Sourcer reported to the Jetliner CIO for all decisions, budgetary or otherwise. Independently, however, Sourcer structured its own IT governance without heeding to its various clients. For all intents and purposes, Sourcer's IT structure did not affect the IT policies of its project groups.

Participants For most interorganizational relationships, executive pairs met, management committees met and operations committees met at every level in order to ensure smooth processes and ensure efficient and frequent communication. Rarely, if ever, were any external participants or consultants involved in any of the interorganizational governance decision-making.

Processes As this relationship existed as a vertical vendor-client relationship, formal authorization was required for all operational IT changes, especially those changes that move against the standard sets set by Jetliner. Authorization could come from various administrative levels at Jetliner, but interorganizational governance processes were often dictated and designed by the executive in charge of the relationship. All of Jetliner IT operations projects and capitalized projects required that the CIO signed off and authorized their budget. Accordingly, all IT improvement projects and changes authorized by Jetliner CIO were passed through to the 
relationship managing executive at Sourcer for execution. This framework for authorization ensured that accountability remained centralized for each partner. Subsequently, authorization of capital went to finance committees first, and they used the "KISS" principle (Keep It Simple, Stupid) to prioritize projects, ensuring that money was fairly allocated while minimizing potential project risk. Joint steering committees - made up of relationship management as well as internal operational consultants from both Jetliner and Sourcer-provided business recommendations to joint executive committees. This way, accountability stayed high and was not passed down the business "ladder".

Success Jetliner adapted its interorganizational governance of IT (IGIT) to its specificities. The choice of Sourcer was made to bring stability and efficiency. Jetliner considered its partnership as a success.

\subsection{Analysis of Jetliner}

Although Jetliner governed its IT from an IT duopoly perspective (Weill, 2004), the interorganizational structure was centralized relative to the outsourcer. At Jetliner, the majority of the IT decision-making occurred under the $\mathrm{CIO}$, though the business executives were consulted whenever the business processes would be affected. Sourcer, as it was an outsourced entity, had two layers of governance: its independent IT governance policies as well as its inherited governance policies. As such, it had to balance between these two in order to maintain effective relations with Jetliner as well as keep up its own internal standards. Sourcer made it a priority to ensure that all of its activities were in the best interest of Jetliner.

Jetliner's IT policies were all governed at the highest level under the CIO. Similarly, all of the interorganizational IT governance policies went through the CIO for approval after having been decided on by joint steering and executive committees. The centrality of this form of accountability was crucial to Jetliner and was in line with their core business values and strategies. At the same time, however, Jetliner admitted that "... sometimes, committees don't work and can be short-sighted, which make them ineffective." This is why they maintained that a central accountability figure was paramount to the success of the IT function and the success of the interorganizational relationship. Furthermore, the multi-sourced processes were seen as mature in order to "get the job done, but are not perfect, as there's still too much hand holding". Evidently, Jetliner and Sourcer had work to be done to perfect this multi-sourced relationship.

Profile The profile of this interorganizational governance of IT is considered contractual since this relationship falls under a centralized governance structure and locus of control, with inward interorganizational processes. The participants of committees are IT executives from both parties, with a focus on Jetliner's CIO for the majority of the decision-making, and a relationship executive manager on Sourcer's side. Jetliner considers itself successful in terms of IT interorganizational governance.

\subsection{Rail}

A major Canadian railway company, heretofore referred to as Rail, had a long history of corporate governance redesigns. Rail evolved through multiple iterations of governance over the past 20 years stemming from an organizational overhaul that coincided with the instatement of a new CEO. Rail saw IT governance as one branch of the considerations of the organization with respect to its business. Traditionally, Rail viewed partnerships as another operations branch of the business, and thus the integrating of both activities - governance and relationship management - made up an emergent sector of development for Rail.

Structure Rail viewed traditional mechanisms of IT governance as taboo; as a former crown corporation, Rail's organizational culture had historically been one of negative connotation with all business activities related to bureaucracy. Rail believed that the organization required looser forms of governance, relying on the flexibility, agility and independent decision-making of its employees. As such, Rail's models of IT governance were constantly fluctuating and changing depending on several factors, including economic state, market fluctuations, intrinsic needs and extrinsic influence and technology. Recently, this form of decentralized decision-making included the IT department, whereby a network IT governance structure ensured this agility and flexibility.

Participants The nature of the IT governance at Rail was made possible by a CIO who participated heavily in several partnerships and associations in order to bolster Rail's competitiveness and advance business practices. Rail relied heavily on their partnerships and associations in order to advance business and increase competitiveness, both within the railway industry and across all transport industries.

Rail belonged to several industry-wide associations, with the ultimate goal of increasing the effectiveness not simply of the organization, but of the industry as a whole. These included:

- Northam, a formal organization, setup by the collective of North American rail firms in order to facilitate in cross-organizational talk about rail standards; 
- ITRail, an organization governed by CIOs of North American rail organizations in order to set standards for IT governance;

- Board, an informal national standards board that meets quarterly to influence "best practice" within the industry and to drive the genesis of standards, allowing for broader checks and balances.

Northam was exempt from anti-trust laws, and had defined standards for information exchange in order to allow for all participants to share in an industry-wide competitive advantage. However, the IT function within this association was directly involved with the business function, and thus there was no separate IT governance credo; rather, there was business governance which covered the IT function; as such, IT was one of many groups - including finance, railway operations, marketing - that participated in this cooperative venture, ensuring that there existed a centralized industry system to control common tasks, improving synchronization and allowing the various rail partners to split the costs, creating economies of scale. The CIO participated to the governing body.

ITRail acted as an industry reference and derived security policies (especially for government agencies, including those involved with homeland security), as well as helped with data interchange policies. Ultimately, there was a need for this organization, and such need was a driving force. The governments formed standards and were imposing policy. There were environmental standards such as SOX, which were required in order to be competitive and successful. ITRail existed for almost a decade and evolved very slowly, with baby steps.

Board had recommended that IT be made an equal partner at the table and that organizations allowed IT to drive processes. For Rail, the bottom-line measure of success was financial gain because it was the most fundamental strategic measure. The business was, after all, market-driven and the product/service offered by any railway organization was very simple. The CIO participated to the governing body.

Processes For each of the participating organizations, committees were formed with a point person/relationship manager - often a relationship executive - from each organization, including Rail, whereby discussions were held to advance all managerial decisions jointly. However, at the same time the industry has grown sufficiently as to reduce the requirement of cooperation and increase competitiveness, and so with each cooperative advance, Rail sought to increase its competitive advantage not simply over other industries, but within the industry as well.

Rail's participant involvement lied heavily on the directorship/executive slant, whereby the CIO participated in most of the informal boards and groups that the railway industry has created, and was often the representative of the IT function for Rail. As such, interorganizational IT concerns were managed from the top down during business exchanges, whereby the industrial effect of informal IT process redesign affects both Rail and its partners, given that each of Rail's industrial partners also participated in these informal executive groups.

Success: Rail considered its approach to interorganizational gouvernance of IT as a success. It is satisfied with the relationship with participants, and judges itself efficient in its use of IT.

\subsection{Analysis of Rail}

Rail saw its position in the market as a cross between competitive drive and cooperative necessity; while it sought to differentiate itself from its competitors in order to capitalize on market opportunities, it was still reliant on partnerships in order to foster industry growth and competitiveness. As such, centralized governance paradigms existed, albeit with decentralized influence. Inter-industrial environmental pressures forced Rail to cooperate with its partners in order to gain market share from other logistics and transport industries, and thus network governance structures with informal influence was where Rail positioned itself strategically. Furthermore, Rail viewed strictly defined governance structures as "weighty", paralleling abundant "bureaucracy", and therefore chose to keep its governance structures fluid, especially from an interorganizational perspective. Rail was consequently classified as network.

Rail touted naturally evolved processes that were self-managed. These governance and control processes relied on the informality of relationship management from an interpersonal perspective; Rail partnership management participants, including directors and executives, viewed the interpersonal aspects of a business relationship as paramount and definitive of the relationship itself, and thus the processes should be flexible enough in order to accommodate changes and unpredicted events. Similarly, Rail's IT management processes, while not industry standard, were heavily influenced by industry, as cooperative ventures required compatible processes between organizations. While Rail could choose, if it wishes, to devise non-standard IT control processes, environmental factors were enough to persuade Rail that standard IT processes, such as electronic data interchange compatibility, were highly advantageous. Rail processes were consequently considered as outward

The relationships that Rail maintained with its partners were mediated by the industry groups, including Northam, ITRail, and Board. The partnerships were longstanding bringing about a certain level of effectiveness in informal 
cooperation and driving informal standards between participants. Rail's governance philosophy was "less is more", as a hands-off approach minimized bureaucracy and allowed the organization to remain agile. At the core of this philosophy was the idea that governance models required an owner, and that owner needed to be accountable. The approach to facilitate such exchanges was to rely on committees.

Profile The profile of this interorganizational governance of IT is considered consensual. The relationships maintained by Rail with its partners falls under a network IT governance structure and locus of control, with informal and non-standardized interorganizational processes. The network governance structure is heavily influenced by industrial groups, and ultimately partnerships. The processes were therefore outward. These industrial groups elicit informal discussion between IT executives, and improvements to the IT structures and processes are brought back to each organization on a regular basis in order to improve the efficiency of IT operations, which required a committee-based approach. Measures of success, in this case, are not formalized nor are they measured; rather, stories of success are conveyed to the industrial partnership groups, and then conclusions are drawn collectively, and disseminated to each organization through its participating executive, namely the CIO. Rail considers itself successful in terms of interorganizational governance of IT.

\section{Discussion}

At Jetliner, there exists a formal structure of decision-making and reporting. Based on the principle that a formal authorization is required for any IT change, a whole decision-making contractual approach has been put in place. First, peer committees exist at three levels: operational, managerial and executive. Each committee makes decision at his level, and the decision is passed on to a higher committee if needed. Second, at the managerial level, joint functional steering committees (such as finance) make business recommendations to a joint executive committee. Finally, all changes need to be approved by the Jetliner CIO before to be implemented. The purpose of the decision-making structure is to hold specific participants accountable for decisions and results. This formal structure that allows each participant to be accountable for their decisions is tightly knit with the IT governance outsourced mode. Authority and accountability have long been identified as key to IT decision-making relative to budget (Bergeron, 1986). This case study suggests that this also applies to IT governance.

The contractual profile fits well to Jetliner since its relationship with participants is contract-based. Although Jetliner is in an interorganizational governance situation, it matches pretty well the definition of contractual governance attributed by Lacity's et al. (2009) in IT outsourcing contexts. Thus, the contractual profile label is used to describe the situation.

Rail has a much more informal structure than Jetliner relative to IT governance. The role of Rail's participants is one of collaboration with its partners. As such it tries to avoid any bureaucratic processes among firms. Thus, company relationship executives meet to address any organizational problems, or situations, including IT, but not specific to IT. At Rail, the directorship relies on the CIO to address specific IT situations. The CIO participates to informal industry boards, and it is by communicating and collaborating with industry representatives that issues are addressed. The networked mode does not give Rail much power. Since participants have no line of authority over their industry partners, the approach is more informative than directive. It is through a consensual approach with soft negotiation and mutual understanding that participants play their role. In this case of networked mechanism, the interorganizational governance of IT is a fragile equilibrium among the executive network partners.

The consensual profile is representative of the Rail situation to the extent that Rail lives in an interorganizational governance of IT where structure, process and participants evolve in a context where culture, beliefs and values are those of collaboration and cooperation. The consensual profile of interorganizational governance of IT goes beyond the relational mode of IT governance developed for outsourcing contexts (Lacity et al., 2009; Fischer, Huber, \& Dibbern, 2011; Leimeister, Yetton, Wüllenweber, \& Krcmar, 2010; Poppo \& Zenger, 2002). At Rail, the interorganizational context is not based on a contract, but rather on a different state of mind which is the search of a consensus beneficial to all concerned parties. The consensual profile label seems more appropriate to this situation.

As summarized in Table 2, Jetliner has a centralized interorganizational IT structure while the Rail interorganizational structure is more characterized by its network. Both companies work with committees although Jetliner's committees exist at three hierarchical levels whereas Rail's committees are built around market representatives where each partner company is conveyed. At Jetliner, the interorganizational IT process is oriented "inward", meaning that the ultimate decision-maker is Jetliner and it is the one who decides of the managerial and 
Table 2. Summary of observations for jetliner and rail

\begin{tabular}{lccccc}
\hline & Interorganizational IT Structure & $\begin{array}{c}\text { Interorganizational IT } \\
\text { Participants }\end{array}$ & Interorganizational IT Process & Result & Profile \\
\hline Jetliner & Centralized & Committee & Inward & Success & Contractual \\
Rail & Network & Committee & Outward & Success & Consensual \\
\hline
\end{tabular}

control processes. Rail has adopted an "outward" interorganizational IT process, seeking advice and collaboration among its business partners. Overall, the type of interorganizational mechanisms used by Jetliner is contractual, while Rail's one is consensual. Despite the pronounced differences among these two cases representing two different gestalts, both companies consider their interorganizational IT governance model as a success.

\section{Conclusion}

Developing profiles of mechanisms for interorganizational governance of IT is a challenging endeavour. The two cases presented above allowed the discovery that mechanisms of interorganizational governance of IT exist and take specific forms in order to successfully support IT collaboration between business partners. Our results were extracted from a larger sample of organizations and were chosen because of their distinctive particularities. Two profiles were uncovered and labeled respectively Contractual and Consensual. The interorganizational mechanisms characterizing the contractual profile are a centralized IT structure, acommittee-baseddecision-making, and an inward IT process. The interorganizational mechanisms characterizing the consensual profile are a network IT structure, a committee-based decision-makingand an outward IT process. Both profiles constitute viable working alternatives since each of them led to success in two different organizational settings. Because of the usual limitations associated with this methodological approach, other profiles might be obtained when other company cases will be analyzed. In future research, it will be interesting to look at the interorganizational governance of IT in other industries like governments since these public institutions might share many similarities with private organizations. Results might also vary among different cultures and organization size. Based on these findings, there is a clear indication that profile-based interorganizational governance of IT should be foremost in the strategic planning of organizations that wish to foster growth and success while maintaining value with their IT investments.

\section{References}

Barney, J. B., \& Ouchi, W. G. (1986). Organizational Economics (pp. 495). San Francisco, CA: Jossey-Bass.

Barringer, B. R., \& Harrison, J. S. (2000). Walking a tightrope: Creating value through interorganizational relationships. Journal of Management, 26(3), 367-403. http://dx.doi.org/10.1177/014920630002600302

Bergeron, F. (1986). Factors influencing the use of DP chargeback information. MIS Quarterly, 10(3), 225-238. http://dx.doi.org/10.2307/249255

Brown, A. E., \& Grant, G. G. (2005). Framing the frameworks: A review of IT governance research. Communications of the Association for Information Systems, 15, 696-712.

Brown, C. V. (1997). Examining the emergence of hybrid IS governance solutions: Evidence from a single case site. Information Systems Research, 8(1), 69-95. http://dx.doi.org/10.1287/isre.8.1.69

Brown, C. V., \& Magill, S. L. (1994). Alignment of the IS functions with the enterprise: Toward a model of antecedents. MIS Quarterly, 18(4), 371-403. http://dx.doi.org/10.2307/249521

Chi, L., \& Holsapple, C. W. (2005). Understanding computer-mediated interorganizational collaboration: A model and framework. Journal of Knowledge Management, 9(1), 53-75. http://dx.doi.org/10.1108/13673270510582965

Chou, F. C., Huang, H. L., \& Chen, U. Y. (2012). The Holistic relationship between supply chain integration and governance forms. In V. Kkachitvichyanukul, H. T. Luong \& R. Pitakoso (Eds.), Proceedings of the $13^{\text {th }}$ Asia Pacific Industrial Engineering \& Management Systems Conference, 1829-1835. Phuket, Thailand.

Croteau, A. M., \& Bergeron, F. (2009). Interorganizational governance of information technology. Proceedings of the $42^{\text {nd }}$ Hawaii International Conference on System Sciences, Big Island, United States.

Croteau, A. M., \& Dubsky, J. (2011). Uncovering modes of interorganizational governance of IT. Proceedings of the $44^{\text {th }}$ Hawaii International Conference on System Sciences, Kauai, United States. 
De Haes, S., \& Van Grembergen, W. (2009). Exploring the relationship between IT governance practices and business/IT alignment through extreme case analysis in Belgian mid-to-large size financial enterprises. $\begin{array}{llll}\text { Journal of Enterprise Information } & \text { Management, 22(5), 615-637. }\end{array}$ http://dx.doi.org/10.1108/17410390910993563

Doz, Y. L., \& Hamel, G. (1998). Alliance advantage. Boston, MA: Harvard Business School Press.

Dubé, L., \& Paré, G. (2003). Rigor in information systems positivist case research: Current practices, trends, and recommendations. MIS Quarterly, 27(4), 597-636.

Dwyer, F. R., Schurr, P. H., \& Oh, S. (1987). Developing buyer-seller relationships. Journal of Marketing, 51, 11-27. http://dx.doi.org/10.2307/1251126

Fischer, T. A., Huber, T. L., \& Dibbern, J. (2011).Contractual and relational governance as substitutes and complements - explaining the development of different relationships. Proceedings of the $19^{\text {th }}$ European Conference on Information Systems, 799-810, Helsinki, Finland.

Gereffi, G., Humphrey, J., \& Sturgeon, T. (2005). The governance of global valuechains. Review of International Political Economy, 12(1), 78-104. http://dx.doi.org/10.1080/09692290500049805

Goo, J., Kishore, R., \& Rao, H. R. (2009). The role of service level agreements in relational management of information technology outsourcing: An empirical study. MIS Quarterly, 33(1), 119-145.

Hall, D. J., \& Saias, M. A. (1980). Strategy follows structures! Strategic Management Journal, 1, 149-163. http://dx.doi.org/10.1002/smj.4250010205

Hamel, G. (1991). Competition for competence and inter-partner learning within international strategic alliances. Strategic Management Journal, 12, 83-103. http://dx.doi.org/10.1002/smj.4250120908

Heide, J. B. (1994). Interorganizational governance in marketing channels. Journal of Marketing, 58, 71-85. http://dx.doi.org/10.2307/1252252

Hong, I. B. (2002). A new framework for interorganizational systems based on the linkage of participants' roles. Information \& Management, 39, 261-270. http://dx.doi.org/10.1016/S0378-7206(01)00095-7

Huxham, C., \& Vangen, S. (2000). Leadership in the shaping and implementation of collaboration agendas: How things happen in a (not quite) joined-up world. The Academy of Management Journal, 43(6), 1159-1175. http://dx.doi.org/10.2307/1556343

Hvalshagen, M. (2004). Transforming the IT organization for the state of Virginia. Information Systems Management, 21(4), 52-61. http://dx.doi.org/10.1201/1078/44705.21.4.20040901/84188.7

IT Governance Institute. (2005). Best practices. Retrieved from http://www.itgi.org/template_ITGI.cfm?Section=Best_PracticesandTemplate=/TaggedPage/TaggedPageDis play.cfmandTPLID $=44$ andContentID $=6574$

Jones, C., Hesterly, W. S., \& Borgatti, S. P. (1997). A general theory of network governance: exchange conditions and social mechanisms. Academy of Management Review, 22(4), 911-945.

Kayworth, T., \& Sambamurthy, V. (2000). Managing the information technology infrastructure. Baylor Business Review, 18(1), 13-14.

Koh, J., \& Venkatraman, N. (1991). Joint venture formations and stock market reactions: An assessment in the information technology sector. Academy of Management Journal, 34, 869-892. http://dx.doi.org/10.2307/256393

Kumar, K., \& van Dissel, H. G. (1996). Sustainable collaboration: Managing conflict and cooperation in interorganizational systems. MIS Quarterly, 20(3), 279-300. http://dx.doi.org/10.2307/249657

Lacity, M., Khan, S., \& Willcocks, L. P. (2009). A review of the IT outsourcing literature: Insights for practice. Journal of Strategic Information Systems, 18(3), 130-146. http://dx.doi.org/10.1016/j.jsis.2009.06.002

Larson, A. (1992). Network dyads in entrepreneurial settings: A study of the governance of exchange relationships. Administrative Science Quarterly, 37, 76-104. http://dx.doi.org/10.2307/2393534

Lee, A. S. (1989). A scientific methodology for MIS case studies. MIS Quarterly, 13(1), 33-50. http://dx.doi.org/10.2307/248698 
Lee, J. N., Miranda, S. M., \& Kim, Y. M. (2004). IT outsourcing strategies: Universalistic, contingency, and configurational explanations of success. Information Systems Research, 15, 110-131. http://dx.doi.org/10.1287/isre.1040.0013

Lee, S., \& Lim, G. G. (2005). The impact of partnership attributes on EDI implementation success. Information \& Management, 42, 503-516.

Leimeister, S., Yetton, P., Wüllenweber, K., \& Krcmar, H. (2010). Relational governance mediates the effect of formal contracts on BPO performance. Proceedings of the $18^{\text {th }}$ European Conference on Information Systems, 1755-1768, Pretoria, South Africa.

Lin, H. F. (2006). Interorganizational and organizational determinants of planning effectiveness for Internet-based interorganizational systems. Information \& Management, 43, 423-433. http://dx.doi.org/10.1016/j.im.2005.10.004

Lowndes, V., \& Skelcher, C. (1998). The dynamics of multi-organizational partnerships: An analysis of changing modes of governance. Public Administration, 76, 313-333 http://dx.doi.org/10.1111/1467-9299.00103

Lu, X. H., Huang, L. H., \& Heng, M. S. (2006). Critical success factors of inter-organizational information systems - A case study of Cisco and Xiao Tong in China. Information \& Management, 43, 395-408. http://dx.doi.org/10.1016/j.im.2005.06.007

Macaulay, S. (1963). Non-contractual relations in business: A preliminary study. American Sociological Review, 28(1), 55-67. http://dx.doi.org/10.2307/2090458

Meyer, N. D. (2004). Systemic IS governance: An introduction. Information Systems Management, 21(4), 23-34. http://dx.doi.org/10.1201/1078/44705.21.4.20040901/84184.3

Oliver, C. (1990). Determinants of interorganizational relationships: Integration and future directions. Academy of Management Review, 15(2), 241-265.

Patrakosol, B., \& Olson, D. L. (2007). How interfirm collaboration benefits IT innovation. Information \& Management, 44, 53-62. http://dx.doi.org/10.1016/j.im.2006.10.003

Peterson, R. (2004). Crafting information technology governance. Information Systems Management, 21(4), 7-22. http://dx.doi.org/10.1201/1078/44705.21.4.20040901/84183.2

Podolny, J. M., \& Page, K. L. (1998). Network forms of organization. Annual Review of Sociology, 24, 57-76. http://dx.doi.org/10.1146/annurev.soc.24.1.57

Poppo, L. \& Zenger, T. (2002). Do formal contracts and relational governance function as substitutes or complements? Strategic Management Journal, 23, 707-725. http://dx.doi.org/10.1002/smj.249

Powell, W. W. (1990). Neither market nor hierarchy: Network forms of organization. Research in Organizational Behavior, 12, 295-336.

Ring, P. S., \& van de Ven, A. H. (1992). Structuring cooperative relationships between organizations. Strategic Management Journal, 13, 483-498. http://dx.doi.org/10.1002/smj.4250130702

Ritter, T. (1999). The networking company. Industrial Marketing Management, 28, 467-479. http://dx.doi.org/10.1016/S0019-8501(99)00075-9

Sambamurthy, V., \& Zmud, R. W. (1999). Arrangements for information technology governance: A theory of multiple contingencies. MIS Quarterly, 23(2), 261-290. http://dx.doi.org/10.2307/249754

Slowinski, G., Seelig, G., \& Hull, F. (1996). Managing Technology—Based Strategic Alliances between Large and Small Firms. SAM Advanced Management Journal, 61, 42-47.

Van Grembergen, W., De Haes, S., \& Guldentops, E. (2004). Structures, processes and relational mechanisms for IT governance. Strategies for Information Technology Governance (pp. 14-36). Hershey, PA: Idea Group.

Wachter, M. L., \& Williamson, O. E. (1978). Obligational markets and the mechanics of inflation. The Bell Journal of Economics, 9(2), 549-571. http://dx.doi.org/10.2307/3003598

Weill, P. (2004). Don't just lead, govern: How top-performing firms govern IT. MIS Quarterly Executive, 3(1), $1-17$. 
Weill, P., \& Ross, J. (2005). A matrixed approach to designing IT governance. MIT Sloan Management Review, 46(2), 25-35.

Weill, P., \& Ross, J. W. (2004). IT governance: How top performers manage IT decision rights for superior results. Boston, Ma: Harvard Business School Press.

Williamson, O. E. (1975). Markets and hierarchies: Analysis and antitrust implications. New York: Free Press.

Winkler, I. (2006). Network governance between individual and collective goals: Qualitative evidence from six networks. Journal of Leadership and Organizational Studies, 12(3), 119-134. http://dx.doi.org/10.1177/107179190601200308

Xue, Y., Liang, H., \& Boulton, W. R. (2008). Information technology governance in information technology investment decision processes: The impact of investment characteristics, external environment, and internal context. MIS Quarterly, 32(1), 67-96.

Zaheer, A., \& Venkatraman, N. (1995). Relational governance as an interorganizational strategy: An empirical test of the role of trust in economic exchange. Strategic Management Journal, 16, 373-392. http://dx.doi.org/10.1002/smj.4250160504

Zarvić, N., Stolze, C., Boehm, M., \& Thomas, O. (2012). Dependency-based IT Governance practices in inter-organisational collaborations: A graph-driven elaboration. International Journal of Information Management, 32(6), 541-549. http://dx.doi.org/10.1016/j.jinfomgt.2012.03.004

Zmud, R. W., Boynton, A. C., \& Jacobs, G. C. (1986). The information economy: A new perspective for effective information systems management. ACM SIGMIS Data Base, 18(1), 17-23. http://dx.doi.org/10.1145/20724.20726

\section{Copyrights}

Copyright for this article is retained by the author(s), with first publication rights granted to the journal.

This is an open-access article distributed under the terms and conditions of the Creative Commons Attribution license (http://creativecommons.org/licenses/by/3.0/). 